\title{
Pengaruh Air Limbah Domestik Terhadap Kualitas Sungai
}

\author{
Destari Anwariani \\ Jurusan Teknik Lingkungan, Fakultas Arsitektur Lanskap dan Teknologi Lingkungan, \\ Universitas Trisakti, Jakarta, Indonesia \\ Email korespondensi: destari08215017@ std.trisakti.ac.id
}

\begin{abstract}
ABSTRAK
Sungai yang memiliki kandungan bahan organik dan anorganik yang tinggi bersumber dari aktivitas masyarakat berupa pembuangan limbah cair ke sungai seperti mandi,cuci, dan kakus (MCK) yang menyebabkan menurunnya kualitas air. Air limbah domestik yang berasal dari hasil buangan dari kegiatan rumah tangga pada bantaran sungai yang langsung dialirkan menuju saluran drainase atau langsung masuk menuju sungai. Meningkatnya debit air limbah domestik yang dihasilkan dapat menyebabkan meningkatnya beban pencemaran air limbah domestik. Pencemaran air limbah domestik dapat menyebabkan meningkatnya parameter fisika, kimia dan biologi dalam air sungai sehingga melebihi batas baku mutu. Kualitas air sungai dilihat dari parameter COD dan BOD yang dibandingkan dengan baku mutu berdasarkan Peraturan Pemerintah No.82 tahun 2001. Karya ilmiah ini dilakukan dengan tujuan untuk mengetahui kontribusi air limbah domestik yang dapat memberikan dampak terhadap kualitas sungai. Masuknya air limbah domestic ke sungai meningkatkan nilai COD dan BOD sehingga menurunkan kualitas air sungai.
\end{abstract}

\section{Kata Kunci: Air Limbah Domestik, Sungai, Kualitas Air}

\section{PENDAHULUAN}

Sumber pencemaran air sangat ditentukan oleh jenis kegiatan serta pemanfaat sumber daya air oleh manusia yang berada disekitar air tersebut. Kualitas air menjadi menurun sebagai akibat dari masuknya berbagai limbah, baik limbah cair maupun padat kedalam aliran air. Tingkat pencemaran sungai dapat mempengaruhi daya tampung sungai. Semakin tinggi tingkat pencemaran sungai maka dapat mengurangi daya tampung bahkan dapat melampaui daya tampung sungai tersebut. Air limbah domestik mengandung sampah padat dan cair yang diantaranya memiliki sifat mengandung bakteri, terdapat bahan orgaik sehingga nilai BOD tinggi, nilai oksigen terlarut rendah, dan mengandung sampah padat dan cair yang mengapung di permukaan. Pencemaran akibat air limbah domestik menyebabkan menurunnya kualitas air sungai dan menurunkan kemampuan dalam mendegradasi bahan organik yang terkandung pada air limbah tersebut. Karya ilmiah ini dilakukan dengan tujuan untuk mengetahui kontribusi air limbah domestik yang dapat memberikan dampak terhadap kualitas sungai.

\section{TINJAUAN PUSTAKA}

\section{Sumber Pencemaran Air Sungai}

Pencemaran air ialah masuknya atau dimasukkannya makhluk hidup, zat, energi dan atau komponen lain ke dalam air oleh kegiatan manusia, sehingga kualitas air menurun sampai ke tingkat tertentu yang menyebabkan air tidak dapat berfungsi sesuai dengan peruntukannya (PP No. 82 Tahun 2001).

Pencemaran air permukaan secara umum dapat berkontribusi terhadap manajemen air yang kurang dan pemakaian bahan kimia pertanian yang tidak teregulasi. Limbah yang 
tidak diolah dari kota dan sektor pertanian langsung masuk ke badan air permukaan tanpa pengolahan. Limbah yang berasal dari sektor industri juga berkontribusi dalam pencemaran air permukaan (Quay, 2018).

Pertumbuhan populasi menyebabkan pencemaran air permukaan, terutama pada air sungai karena terbatasnya manajemen sanitasi dan limbah domestik. Kekurangan pengelolaan limbah domestik dan perilaku manusia yang berlaku secara tidak langsung membuang limbah organik dan anorganik serta limbah padat dan cair ke badan air, telah meningkatkan tingkat polusi air dan menurunkan kualitas air (Suswati dan Wibisono, 2013 dalam Susanti, dkk, 2017).

Sumber pencemaran air yang berasal dari limbah domestik umumnya berasal dari kawasan permukiman penduduk. Air limbah cair yang berasal dari hasil kegiatan manusia masuk ke perairan melalui limpasan yang bersumber dari wilayah pertanian, permukiman dan perkotaan (Sahabuddin, 2014). Banyaknya aktifitas di sekitar sungai dapat menyebabkan pencemaran dan mempengaruhi serta menurunkan kualitas air, selain aktifitas manusia faktor lain yang dapat menyebabkan terjadinya pencemaran adalah perubahan iklim (Zanatia, 2019).

\section{Kajian Terhadap Parameter Kualitas Air}

Kualitas air sungai dipengaruhi oleh tata guna lahan. Kemampuan daya tampung air sungai secara alamiah terhadap pencemaran harus tetap dipertahankan untuk meminimalkan terjadinya penurunan kualitas air sungai (Marfai Aris, 2004 dalam Pohan dkk, 2016).

Kualitas air dapat diketahui dengan melakukan pengujian di laboratorium. Pengujian kualitas air dilakukan dengan menguji parameter fisik, kimia, dan biologi seperti bau dan warna. Parameter kualitas air terdiri dari parameter fisika yaitu suhu, kekeruhan, dan sebagainya), parameter kimia terdiri dari COD, BOD, $\mathrm{pH}$, DO dan sebagainya, dan parameter biologi seperti keberadaan bakteri dan sebagainya (Sahabuddin dkk, 2014).

Partikel senyawa organik yang berasal dari kegiatan domestik manusia dapat ditemukan sebagai partikel koloid dan kasar yang dapat menyebabkan cahaya terhalang masuk kedalam air sehingga menyebabkan kekeruhan menjadi tinggi (Widyatmoko dkk, 2010).

Nilai $\mathrm{pH}$ yang rendah mengindikasikan bahwa terjadinya penurunan kualitas perairan yang nantinya berdampak terhadap kehidupan biota air. Akibat dari perubahan ini akan membunuh biota yang paling toleran sekalipun, hal ini dikarenakan jaringan makanan pada perairan terganggu (Susana, 2009). Selain perubahan $\mathrm{pH}$, konsentrasi oksigen terlarut yang berubah juga dapat mengindikasikan terjadinya perubahan kualitas air dimana semakin rendah konsentrasi oksigen terlarut maka semakin rendah kualitas perairan (Welch, 1980 dalam Susana, 2009).

Lingkungan dapat tercemar jika dimasuki atau kemasukan bahan pencemar yang dapat mengakibatkan gangguan pada makhluk hidup yang ada di dalamnya (Bahtiar, 2007). Menurunnya kualitas air ditandai dengan perubahan warna air dan bau. Menurut Peraturan Pemerintah Nomor 82 Tahun 2001 pencemaran air dan sungai dikatakan tercemar apabila kualitasnya sudah tidak sesuai dengan peruntukannya. (Pohan dkk, 2016).

\section{Dampak Air Limbah Domestik}


Menurut UU Nomor 18 Tahun 2008, limbah domestik merupakan limbah yang berasal dari kegiatan sehari-hari tetapi tidak termasuk aktivitas kakus. Kegiatan seharihari yang menghasilkan limbah seperti mencuci, memasak, mandi, dan kegiatan pertanian serta peternakan.

Menurut Keputusan Menteri Lingkungan Hidup Nomor 68 tahun 2016 yang dimaksud dengan air limbah rumah tangga atau air limbah domestik adalah air limbah yang merupakan hasildari usaha dan atau kegiatan permukiman, rumah makan, perkantoran, perniagaan, apartemen, dan asrama.

Air limbah domestik dapat terbagi menjadi blackwater dan greywater. Definisi greywater adalah air limbah yang berasal dari dapur, air bekas cuci pakaian, dan air mandi. Sedangkan blackwater adalah air limbah yang mengandung kotoran manusia (Purwatiningrum, 2018). Sungai yang memiliki kandungan bahan organik dan anorganik yang tinggi bersumber dari aktivitas masyarakat berupa pembuangan limbah cair ke sungai seperti mandi,cuci, dan kakus (MCK), hal ini menyebabkan menurunnya kualitas air (Tarigan dkk, 2013). Kegiatan industri, domestik, dapat berdampak negatif terhadap sumber daya air seperti penurunan kualitas air, hal ini dapat mengganggu dan menimbulkan kerusakan bagi makhluk hidup di air (Effendi dalam Sasongko, 2014).

Perubahan pola dan pemanfaatan lahan menjadi lahan pertanian dan permukiman serta diiringi dengan meningkatnya industry memberikan dampak terhadap kondisi hidrologis. Aktivitas manusia yang berasal dari kegiatan industri, pertanian, dan rumah tangga akan memberikan dampak terhadap penurunan kualitas air sungai (Suriawiria, 2003 dalam Agustiningsih, 2012).

Berikut merupakan hasil penelitian sebelumnya mengenai pengaruh masuknya air limbah domestik terhadap pencemaran sungai yang menyebabkan kualitas air sungai menurun.

Tabel 1. Hasil Penelitian Pendahuluan

\begin{tabular}{|c|c|c|}
\hline Judul Paper, tahun & Penulis & Hasil Penelitian \\
\hline $\begin{array}{l}\text { The Study Of Water } \\
\text { Quality Status In The } \\
\text { Ngebrong River With } \\
\text { Physical And Chemical } \\
\text { Parameters In The } \\
\text { Tawangsari Barat } \\
\text { Region, Pujon District, } \\
\text { Malang Regency, } 2019\end{array}$ & $\begin{array}{l}\text { Bambang Suharto, Liliya } \\
\text { Dewi, Aulia Nur } \\
\text { Mustaqiman, Tyas Roro } \\
\text { Anggraini Kyai Marjo }\end{array}$ & $\begin{array}{l}\text { - Konsentrasi BOD pada bagian hulu lebih } \\
\text { tiggi yaitu sebesar } 8,38 \mathrm{mg} / \mathrm{L} \text { dibandingkan } \\
\text { bagian hilir sebesar } 7,12 \mathrm{mg} / \mathrm{L} \text {, hal tersebut } \\
\text { menunjukkan kualitas air yang rendah yang } \\
\text { disebabkan oleh kandungan limbah organik } \\
\text { tinggi } \\
\text { - Konsentrasi COD terbesar berada pada } \\
\text { bagian hilir yaitu sebesar } 21,75 \mathrm{mg} / \mathrm{L} \text {, hal } \\
\text { tersebut menunjukkan kualitas air yang } \\
\text { rendah yang disebabkan oleh kandungan } \\
\text { limbah organik tinggi }\end{array}$ \\
\hline $\begin{array}{l}\text { The Characteristics Of } \\
\text { Domestic Wastewater } \\
\text { From Office Buildings In } \\
\text { Bandung, West Java, } \\
\text { Indonesia, } 2018\end{array}$ & $\begin{array}{lr}\text { Vandith Va, Ahmad Soleh } \\
\text { Setiyawan, } & \text { Prayatni } \\
\text { Soewondo, } & \text { Dyah } \\
\text { Wulandari Putri } & \end{array}$ & $\begin{array}{l}\text { - Kualitas air limbah domestik dari rumah } \\
\text { tangga lebih tinggi dibandingkan air limbah } \\
\text { dari bangunan perkantoran } \\
\text { - Perbandingan COD/BOD air limbah dari } \\
\text { bangunan perkantoran hanya sebesar } 0,2 \\
\text { lebih rendah dibandingkan air limbah yang } \\
\text { berasal dari rumah tangga }\end{array}$ \\
\hline $\begin{array}{lr}\text { Studi Penentuan } & \text { Daya } \\
\text { Tampung } & \text { beban } \\
\text { Pencemaran } & \text { Sungai } \\
\text { Akibat Buangan } & \text { Limbah } \\
\text { Domestik, 2014 } & \end{array}$ & $\begin{array}{ll}\text { Komang Della } & \text { Pavita, } \\
\text { Bambang } & \text { Rahadi } \\
\text { Widiatmono, Liliya Dewi }\end{array}$ & $\begin{array}{l}\text { - Terdapat kenaikan konsentrasi TSS di } \\
\text { sungai sebesar 30,6\%, konsentrasi BOD } \\
\text { sebesar 42,5 \%, konsentrasi COD sebesar } \\
49,6 \% \text {, dan nitrat sebesar 22,7\% pada } \\
\text { kondisi air sungai setelah mendapat } \\
\text { masukan air limbah domestik }\end{array}$ \\
\hline
\end{tabular}




\begin{tabular}{|c|c|c|}
\hline Judul Paper, tahun & Penulis & Hasil Penelitian \\
\hline & & $\begin{array}{l}\text { - Terdapat penurunan nilai DO sebesr } 11 \% \\
\text { pada kondisi air sungai sudah mendapat } \\
\text { masukan air limbah }\end{array}$ \\
\hline $\begin{array}{l}\text { Kontribusi } \\
\text { Domestik Penduduk Di } \\
\text { Sekitar Sungai Biknoi } \\
\text { Terhadap Kualitas Air } \\
\text { Bendungan } \\
\text { Sebagai Sumber Baknoi } \\
\text { Minum Serta Upaya } \\
\text { Penanganannya, 2016 }\end{array}$ & $\begin{array}{l}\text { Maya Roman, Fransiskus } \\
\text { Kia Duan, Suwari }\end{array}$ & $\begin{array}{l}\text { - Potensi beban pencemar terbesar oleh } \\
\text { parameter COD sebesar } 28.996 \text { ton/bulan, } \\
\text { TSS sebesar } 13180 \text { ton/bulan, parameter } \\
\text { BOD sebesar } 12.982 \text { ton/bulan } \\
\text { - Beban pencemar terendah untuk parameter } \\
\text { fosfat sebesar 263,6 ton/bulan }\end{array}$ \\
\hline $\begin{array}{l}\text { Kajian perhitungan beban } \\
\text { pencemaran air sungai di } \\
\text { daerah sungai } \text { (DAS) } \\
\text { Cikapundung dari sektor } \\
\text { domestik, } 2018\end{array}$ & $\begin{array}{ll}\text { Yushi Rahayu, } & \text { Iwan } \\
\text { Juwana, } & \text { Dyah } \\
\text { Marganingrum } & \end{array}$ & $\begin{array}{l}\text { - Potensi beban pencemar BOD sebesar } \\
2.102,66 \mathrm{~kg} / \mathrm{hari} \text { dan beban pencemar } \\
\text { sebesar } 2.622,14 \mathrm{~kg} / \mathrm{hari} \\
\text { - Potensi beban pencemar COD sebesar } \\
3182,76 \mathrm{~kg} / \mathrm{hari} \text { dan beban pencemar } \\
\text { sebesar } 11.880,72 \mathrm{~kg} / \mathrm{hari} \\
\text { - BOD menyumbang } 80,19 \% \text { pencemaran } \\
\text { yang berasal dari limbah domestik } \\
\text { - COD menyumbang 26,78\% pencemaran } \\
\text { yang berasal dari limbah domestik }\end{array}$ \\
\hline
\end{tabular}

Pembuangan limbah domestik di sungai dapat meningkatkan kadar BOD dalam air. Kandungan nilai BOD yang tinggi di sungai dapat menyebabkan pendangkalan akibat sedimentasi di sungai. Hal ini dikarenakan berkurangnya kadar oksigen dalam air yang masuk sehingga biota akan mengalami kematian (Suprihatin, 2014).

\section{PENUTUP}

Banyaknya aktifitas di sekitar sungai salah satunya adalah kegiatan domestik dapat menyebabkan pencemaran dan mempengaruhi serta menurunkan kualitas air. Meningkatnya debit air limbah domestik yang dihasilkan dapat menyebabkan meningkatnya beban pencemaran air limbah domestik sehingga dapat menurunkan kualitas air di sungai. Pencemaran air limbah domestik dapat menyebabkan meningkatnya komposisi bahan organik di dalam sungai dan meningkatkan nilai COD dan BOD yang menyebabkan berkurangnya oksigen di dalam air sungai dan menurunkan kualitas air sungai. Tingginya tingkat pencemaran sungai maka dapat mengurangi daya tampung bahkan dapat melampaui daya tampung sungai tersebut. Kegiatan manusia di sekitar bantaran sungai menghasilkan air limbah rumah tangga yang langsung dibuang ke saluran drainase atau sungai yang menyebabkan kualitas sungai menjadi tercemar. Penanggulangan terhadap pencemaran air limbah domestik dapat dilakukan dengan membangun Instalasi Pengolahan Air Limbah (IPAL) sehingga air limbah dari rumah tangga dapat diolah terlebih dahulu sebelum dialirkan langsung ke sungai atau saluran drainase.

\section{DAFTAR PUSTAKA}

Agustiningsih, Dyah. 2012. Analisis Kualitas Air Dan Strategi Pengendalian Pencemaran Air Sungai Blukar Kabupaten Kendal. Jurnal Presipitasi Vol. 9 No.2 September 2012, ISSN 1907-187X.

Keputusan Menteri Lingkungan Hidup Nomor 68 Tahun 2016 tentang Mutu Air Limbah Rumah Tangga 
Pavita, Komang Della, dkk. 2014. Studi Penentuan Daya Tampung Beban Pencemaran Sungai Akibat Buangan Limbah Domestik (Studi Kasus Kali Surabaya - Kecamatan Wonokromo). Jurnal Sumberdaya dan Lingkungan.

Peraturan Pemerintah No.82 Tahun 2001 tentang Pengelolaan Kualitas Air Dan Pengendalian Pencemaran Air.

Pohan, Dedy Anwar Saleh. 2016. Analisis Kualitas Air Sungai Guna Menentukan Peruntukan Ditinjau Dari Aspek Lingkungan. Jurnal Ilmu Lingkungan Volume 14 Issue 2(2016): 63-71

Purwatiningrum, Oktina. 2018. Gambaran Instalasi Pengolahan Air Limbah Domestik Komunal di Kelurahan Simokerto, Kecamatan Simokerto, Kota Surabaya. Jurnal Kesehatan Lingkungan Vol. 10, No. 2 April 2018: 243-253.

Quay, Coleman. 2018. Water Quality Impacts of the Citarum River on Jakarta and Surronding Bandung Basin. Bachelor of Science Degree. Ohio State University.

Rahayu, Yusi, dkk. 2018. Kajian perhitungan beban pencemaran air sungai di daerah sungai (DAS) Cikapundung dari sektor domestik. Jurnal Rekayasa Hijau No.1 Vol.2 ISSN: 2550-1070

Roman , Maya, dkk. 2016. Kontribusi Limbah Domestik Penduduk Di Sekitar Sungai Biknoi Terhadap Kualitas Air Bendungan Biknoi Sebagai Sumber Bakuair Minum Serta Upaya Penanganannya. Jurnal Bumi Lestari, Volume 16 No. 2, Agustus 2016

Sahabuddin, Hartina, dkk. 2014. Analisa Status Mutu Air Dan Dayatampung Beban Pencemaran Sungai Wanggu Kota Kendari. Jurnal Teknik Pengairan, Volume 5, Nomor 1, Mei 2014, hlm 19-28.

Sasongko, Endar Budi, dkk. 2014. Kualitas Air Dan Penggunaan Sumur Gali Oleh Masyarakat Di Sekitar Sungai Kaliyasa Kabupaten Cilacap. Jurnal Ilmu Lingkungan Volume 12 Issue 2: 72-82 (2014).

Suharto, Bambang, dkk. 2019. The Study Of Water Quality Status In The Ngebrong River With Physical And Chemical Parameters In The Tawangsari Barat Region, Pujon District, Malang Regency. Indonesian Journal of Urban and Environmental Technology Vol.2 No.2 April, 2019, 164-180.

http://dx.doi.org/10.25105/urbanenvirotech.v0i0.4361

Suprihatin, H. 2014. Kalilo river pollution due to limited land settlement and human behavior along the Kalilo riverbanks. Journal Of Degraded And Mining Lands Management Volume 1, Number 3.

DOI:10.15243/jdmlm.2014.013.143

Susana, Tjutju. 2009. Tingkat Keasaman (Ph) Dan Oksigen Terlarut Sebagai Indikator Kualitas Perairan Sekitar Muara Sungai Cisadane. Jurnal Teknik Lingkungan Vol 5 No.2 Des. 2009, 33-39.

Susanti, Pranatasari Dyah, Arina Miardini. 2017. The impact of Land use Change on Water Pollution Index of Kali Madiun Sub-watershed. Forum Geografi, 31(1), 2017. DOI: 10.23917/forgeo.v31i1.2686

Tarigan, Adianse, dkk. 2013. Kajian Kualitas Limbah Cair Domestik Di Beberapa Sungai Yang Melintasi Kota Manado Dari Aspek Bahan Organik Dan Anorganik. Jurnal Pesisir dan Laut Tropis Volume 1 Nomor 1 Tahun 2013.

Undang Undang Nomor 18 Tahun 2008 tentang Pengelolaan Sampah

Va, Vandith, dkk. 2018. The Characteristics Of Domestic Wastewater From Office Buildings In Bandung, West Java, Indonesia. Indonesian Journal of Urban and Environmental Technology Vol 1 No.2 April 2018. http://dx.doi.org/10.25105/urbanenvirotech.v1i2.2826 
Widyatmoko, H, Bambang Iswanto, Roro Ira Riandiani. 2010. Penguraian Sampah Organik Di Muara Kali Kresek Jakarta Utara Berdasarkan Kondisi Sungai Dengan Parameter Bod, Cod, Dan Zat Organik. Jurnal Teknologi Lingkungan Vol.5 No.3 Juni, 2010, 107-112.

http://dx.doi.org/10.25105/urbanenvirotech.v5i3.680

Zanatia, Khalida Firda, Hikmaya Aji Ningrum, Agung Rahmadi. 2019. Pencemaran Air di Daerah Aliran Sungai Cimencrang Jawa Barat: Sumber, Dampak, dan Solusi. Jurusan Agroteknologi Fakultas Sains dan Teknologi UIN Sunan Gunung Djati Bandung. 